\title{
Entrepreneurial Survival Values on Tanggui Craftsmen Within the Creative Economy Context
}

\author{
Ika Sakti Wulandari ${ }^{1 *}$ Rizali Hadi ${ }^{1}$ Muhammad Rahmattullah ${ }^{1}$ Ananda Setiawan ${ }^{1}$ \\ ${ }^{1}$ Department of Economic Education, Faculty of Teacher Training and Education, Lambung Mangkurat University, \\ Banjarmasin 70123, Indonesia \\ ${ }^{*}$ Corresponding author. Email: ika.bsu97@gmail.com
}

\begin{abstract}
This research is intended to describe the values of entrepreneurship survival on the tanggui craftsmen in Alalak Selatan district located on Banjarmasin city. This research uses descriptive qualitative approach and primary data source obtained through observations and in-depth interviews using analysis technique of Miles and Huberman. The key informants in this research are tanggui craftsmen. The results show that the values of entrepreneurship survival are still developed and adopted among the tanggui craftsmen. Those values are manifested within strategy forms which are: 1) customer selection as the strategy for winning the market; 2) product heterogeneity in shape, size and price as the product expansion; 3) selling price strategy to increase customer demand; and 4) product quality strategy based on raw material quality and tidiness of the product. Those developing values are being affected by some factors such as: 1) environmental conditions such as accessible raw material, tradition, culture and kinship value embraced by the society; 2) the personal characteristic of the founder; 3) using 'bekawanan' strategy as the industry structure; and 4) having related work experience before starting the profession as a tanggui craftsmen.
\end{abstract}

Keywords: Values, survival, entrepreneurship, and tanggui.

\section{INTRODUCTION}

The development of science and technological advances has at least contributed to the changing patterns of the economic life of the community globally as in production, consumption and distribution. In addition, with the constant innovation emerging from the community, it is not only the economic pattern of society that had changed, but also shifted the economic orientation that had existed since centuries ago. The shifting of economic orientation starts from the changing process from agricultural economics to industrial economics, industrial economics to information Economics (e-commerce), and economic information (ecommerce) to the creative economy.

Creative economy relies more on the excellence of human resources that process natural resources into a work derived from the creative ideas of human thought to develop a country's economy. Presidential instruction No. 6 year 2009 mentions the definition of creative economy is an economic activity based on the creativities, skills, and abilities of individuals to create a creative mindset and copyright that are economically valuable and influential in the society welfare. The contribution of the creative economy sectors in Indonesia's export in Indonesia has been consistently recording positive growth with the average of $6.93 \%$ per year. The creative economy posted strong growth since 2013 contributing $641,815.4$ billion IDR to the country's GDP. The creative sectors posted strong growth year by year as seen as in 2015 contribute 852.24 trillion and by the end of the year 2016 reached 922.59 trillion IDR which accounted for $7.44 \%$ of Indonesia's GDP.
The creative economy in Indonesia is comprised of 16 subsectors, yet not all subsectors can be used as export commodities. The craft subsector is the second largest creative economic export commodity after fashion. Both of these commodities accounted for $90 \%$ of the total creative economic sectors with a total value of $10,901,481$ thousand US $\$$ for the fashion subsector and 7,797,661.1 thousand US \$ for its craft subsectors. Even though fashion subsector is becoming the first largest commodity to be exported in Indonesia, in the South Kalimantan province the main subsector that has been the main export commodity is handicrafts with the total exports as much as $316,419 \mathrm{Kg}$ and export value of US $\$ 7,647,047$ in 2016 (creative economic exports 2010-2016, BPS) and the Banjarmasin city ranks top in the potential of creative industries of craft [1].

One of the craft products originally from South Kalimantan is Tanggui. Tanggui is a round-shaped hat commonly used as a head cover by the local people. The shape of tanggui is round hat (caping) made from woven Nipah leaves that use to protect the head from heat and rain [2]. Local farmers usually uses Tanggui when the harvest time comes. Tanggui is also widely used by the floating market merchants as a characteristic of its market [3]. The main production of Tanggui on Banjarmasin City is located in the South Alalak district, dominated by the Banjarnese ethnics.

Based on the observation results, the development of Tanggui from time to time is quite good because the market demand of tanggui craft is still growing. On the other hand, 
the number of craftsmen in general has decreased and some of them has survived. According to the fact about survived Tanggui craftsmen indicate the existence of special values embraces and develops continuously in their lives. [4] states a value as a conception, explicit or implicit, a distinct view of the individual or group about what is desirable that can influence the mode, meaning and final action to be made. Value is a reference about how is someone must behave and commit through a mental formation formulated from human behavior [5]. These values are contained in various activities of life, especially economic activity and an occupation as a Tanggui craftsmen.

The existence of the values that adopt and underlie the craftsmen's behavior who are also an entrepreneur to keep running and maintaining their business into an interesting phenomenon will be studied further. Survival is essentially the ability of certain systems, communities or communities to harm the right to withstand, absorb, accommodate and recover from the effects of danger in a timely and efficient manner, including by means of preservation and recovery of basic essential structures and functions [6]. The business survival consider as an important issue because it plays an important role in economic development [7].

The survival and the continuity of a business in practice cannot be separated from the scope of entrepreneurship. This is because the function of entrepreneurship itself is to innovate and a non-innovate business will not be able to survive [8]. The concept of entrepreneurship essentially refers to the nature, characteristic and feature inherent to a person who has a willpower to bring innovative and creative ideas into real business and can develop them strongly [9]. While [10] said the innovation in an effort requires the knowledge, skills and creativity of a person in question. The nature, characteristic and feature are reflected in the craftsmen Tanggui in South Alalak distric who always work hard and provide innovation as their best product results. The encouraging value to maintain its business as a craftsman Tanggui as an entrepreneurial producing creative products, as a basis to examine the values of entrepreneurial sustainability that develops in the craftsmen Tanggui in Alalak Selatan.

\section{METHOD}

This research uses qualitative descriptive approach. The approach use to identify the survival values on tanggui craftsmen residing in the South Alalak district, Banjarmasin city. The location of this conducted research is in South Alalak district, which is also being a center production of tanggui crafts. Researcher role in this research as the main instruments involved directly in the study.
This research use primary data sources that can be interpreted as a main data obtained directly from observation, interview and documentation with some related parties, who are the tanggui craftsmen lived in the South Alalak district. The subject in this study is a society that still works as a Tanggui craftsmen in the South Alalak village which is restricted to four people namely Acil Sariyah, Acil Warna, Acil Arbiyah and Acil Bainah. The subject selection of this research is based on the differences of background, environment, and skill to support their profession as a tanggui craftsmen. The purpose of this subject selection is to obtain information that will be used to determine how the entrepreneurship survival values of the tanggui craftsmen works.

Data collected through the observations, interviews and documentations. The data analysis in this research uses Milles and Huberman models consisting of data collection, data reduction, data display and data verification. Data credibility test use the triangulation and reference material. Triangulation is a method of data checking from various sources in different ways and times. The type of triangulation that will be used in this research is called triangulation technique that usually use to test the credibility of various data by checking them to the same source with different techniques to interpret the purpose of this research or to determine how the entrepreneurship survival values on the tanggui craftsmen works.

\section{RESULT AND DISCUSSION 3.1 Entrepreneurial survival strategy of Tanggui craftsmen}

\subsubsection{Strategy to wins market competition}

Tanggui craftsmen in maintain their business have their own strategy to win the market competition by selecting customers and determining their own target market. [11], describes the market targeting is a process of actions perform by entrepreneurs to choose one or more market segments that want to be entered. The target market chosen by Tanggui craftsmen is the surrounding community that has become a regular customer. The reason behind this customer selection as their market targeting are: 1) to minimize the losses that may occur; 2) cost for production derived from the customers. In this case, customers give money as their first payment of tanggui to the craftsmen and the craftsmen use it as the production cost. Even though the craftsmen have determined the target market, they also sell their products to other customers for urgent economic needs. The market targeting strategy to win the competition by tanggui craftsmen can be seen in Figure 1. 


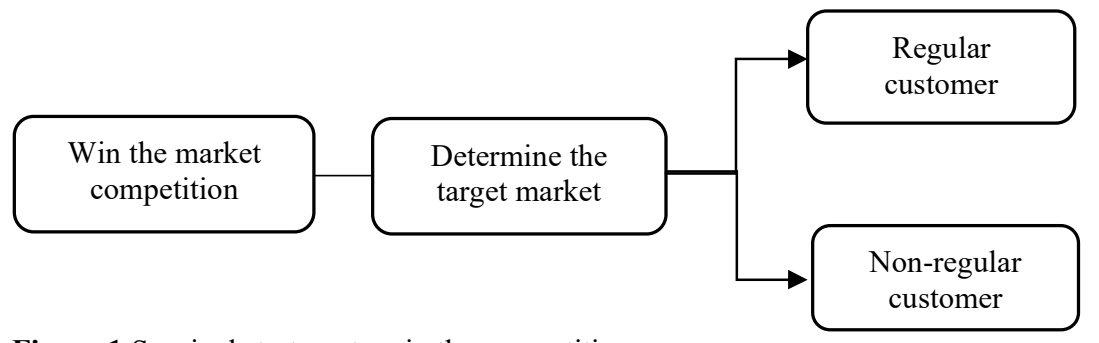

Figure 1 Survival strategy to win the competition

\subsubsection{Product development Strategy}

Product development is done by craftsmen to keep their business survive. The product development is consisting variation or heterogeneity of the product. [12] determine product variation as the strategy of the company by diversifying their products in order to give what the customer wants. The development of products found on the Tanggui business is based on three aspects which are: heterogeneity on size, heterogeneity on type, and heterogeneity on price (Fig. 2).

Heterogeneity based on size, the tanggui product has three variations in size, which are: 1) small size that is usually used as a souvenir, 2) medium size that is usually used as a head cover, and 3) large size that is usually used for other purposes of the customer. The heterogeneity of Tanggui by type, namely the bakal tanggui, ordinary tanggui and ornamental tanggui. The emergence of ornamental Tanggui is caused by different importance of the customer. The main function of tanggui is to cover the head, but recently the function is switching to be a dance property or interior décor property. Heterogeneity based on the price that can be found in different pricing strategy according to the size and type of Tanggui itself. Normally, bakal tanggui cost IDR $1,700.00$ to IDR 2,000.00. Ordinary Tanggui prices IDR $10,000.00$ to IDR $20,000.00$ and ornamental Tanggui prices IDR 50,000.00.

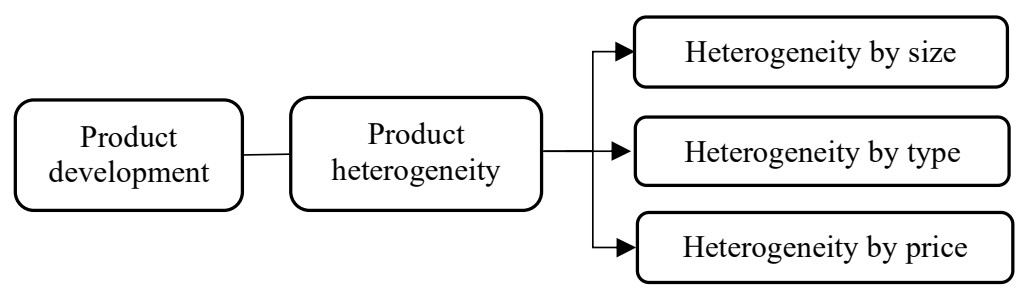

Figure 2 Survival strategy based on product development

\subsubsection{Pricing strategies to increase customer demand}

The determination of selling price is actually a freedom for any of producers to sell their product remembering the selling price principle that should be able to cover the full cost plus a reasonable profit [12]. The selling price is equal to the production cost plus desired profit mark-up. From that definition can be said that the sale price is a certain amount of costs issued by the company to produce a product or service plus the desired percentage of profit. The finding shows that the selling price from Tanggui craftsmen based on the calculation of total cost and the agreement between the other craftsmen (Fig. 3). The cost plus pricing determine by calculating the total cost of raw materials and desired profit. The selling price of Tanggui can also be determined by the agreements resulting in the meeting between other craftsmen. However it is not impossible to found a bargain between the tanggui craftsmen and the customer. This bargaining selling methods is one of the method bringing the profit to the craftsmen. The appropriate selling price can increase the demand of tanggui product to be expected.

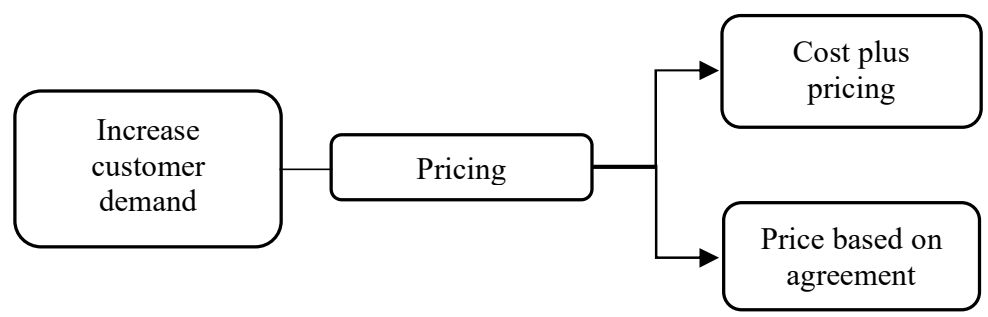

Figure 3 Survival strategies based on pricing 


\subsubsection{Strategy to ensures product quality}

Quality is a strategy that applied by tanggui craftsmen to be able to survive. Quality of their product is used to convey the excellence of status and position, and ownership of goods that have "good quality" will make the owner distinct from others who cannot afford it [13]. Based on the result finds on Tanggui craftsmen, they apply two ways to keep the quality of Figure 4. Survival strategy based on product quality

Tanggui. The first quality is determined on the raw material they used to make a tanggui. The second quality is determined by the product's neatness (Fig. 4). The more good raw materials is, the better quality of tanggui the craftsmen can produce. Craftsmen are found to be very attentive to the processing of raw materials in order to produce a nice and neat (bengkeng) tanggui

Aside from the quality aspect of raw materials, the quality of tanggui can be determined from the neatness during the production process. Tanggui craftsmen are found to have great sympathy on prospective buyers proved by the eagerness to make the best quality of their product. They believe that the customer will be satisfied if the Tanggui they bought have a best quality.

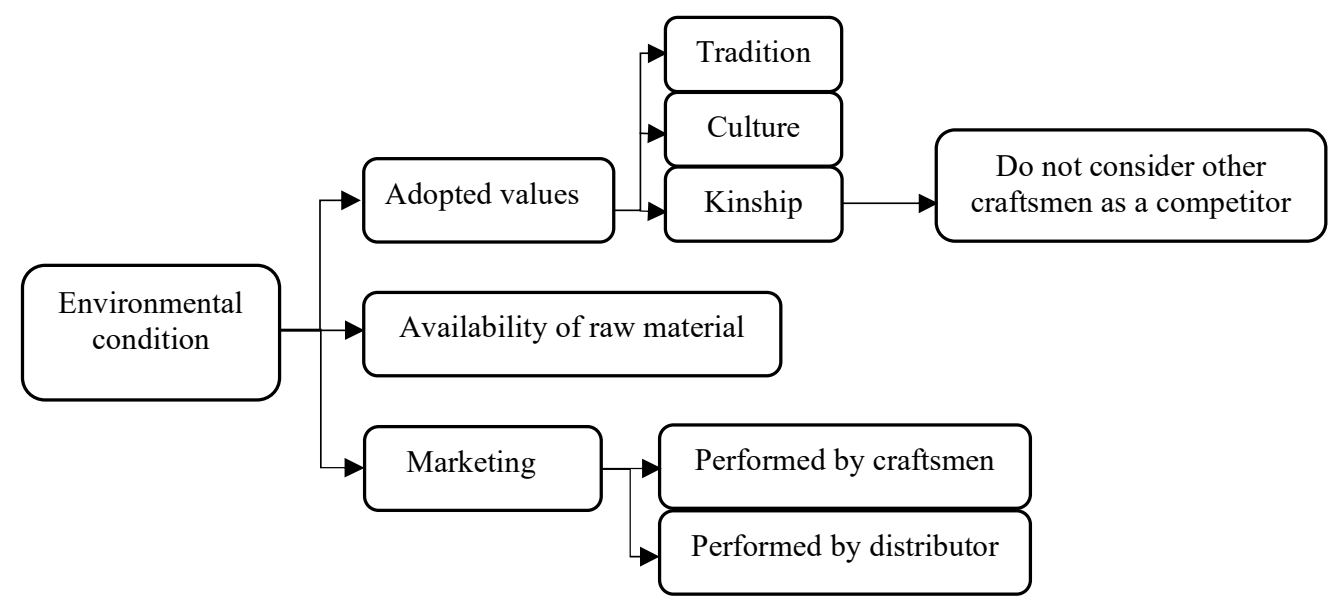

Figure 4 Survival strategy based on product quality

\subsection{Entrepreneurial survival factor of Tanggui craftsmen}

Survival is essentially an ability of certain systems, community or society to protect the right to withstand, absorb, accommodate and recover from the effects of danger in a timely and efficient manner, through preservation and important recovery of basic structures and functions. [14] in his study explains that in order to survive, a business depends on several aspects of environmental conditions, industrial structures, business characteristics, and activities undertaken by the founder of the business before starting Business. These four aspects of the study are described as follows.

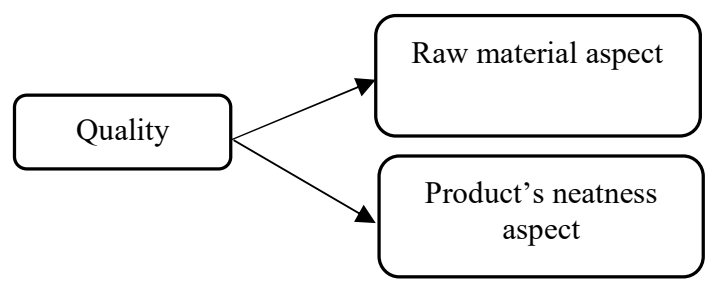

Figure 5 The survival factor of environmental conditions

\subsubsection{Environmental condition factors}

Environmental conditions in this finding is the environmental conditions that develop around the craftsmen' residence. Environmental conditions factor, after going through the observation phase and a deep interview with the Tanggui craftsmen in South Alalak district, researchers found that there are some aspects that do make them choose to survive in this modern era. Those aspects that affect the environmental conditions are: 1) the presence of adopted values, 2) the availability of raw materials and 3) marketing (Fig. 5). 


\section{1) Adopted Values}

The business of Tanggui in the perspective of the community of Southern Alalak is a business that has been passed down for generations and is a tradition that cannot be abandoned. According to [15] the tradition derives from the word tradere which means to divert, to convey and to hand over to be forwarded. In this context, the meaning of tradition is interpreted as something passed down and still preserved by society.

The tradition or culture that develops and still continues preserve by craftsmen and communities in the South Alalak district is generally shown from the aspect of their behavior that cannot be separated from the existence of Tanggui.It is reflected from the explanation of the interviewee mentioned that inside every small boat (jukung), there is always a tanggui. [16] argues that the survival of a culture can describe the extent of the culture's

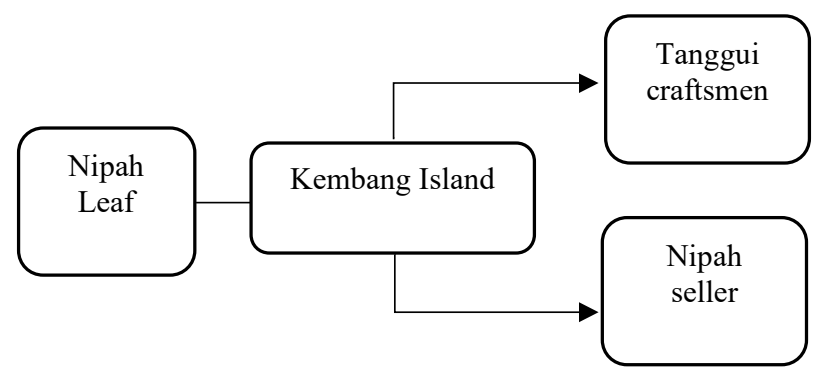

Figure 6 Raw material distribution channel type 1

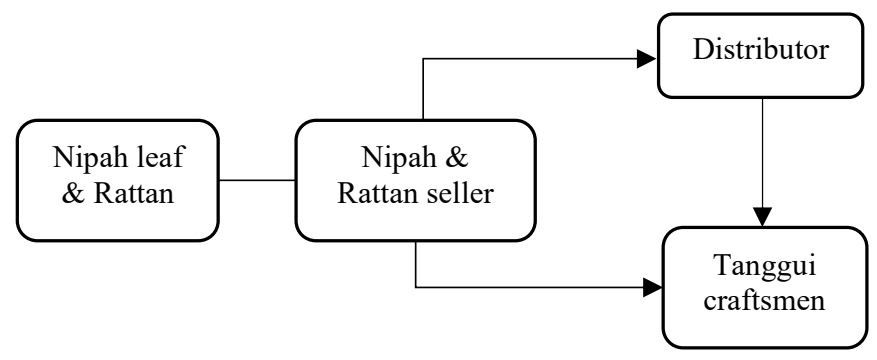

Figure 7 Raw Material distribution channel type II

\section{3) Marketing}

Marketing of tanggui in South Alalak village there are two types, through personal marketing characterized by the presence of customers who come directly to the house of craftsmen to order Tanggui, and through the distributor that act as marketers distributing Tanggui products to be processed further to other craftsmen and marketed outside the city of Banjarmasin. strength in addressing the development of the region. The kinship value is the third value held firmly by the Tanggui craftsmen, according to [17] kinship value is a noble value because it has a high position in the society. The kinship value in the society appears as a result of good relationship between the families or the friendship that is embodied in non-competitive behavior among the craftsmen.

2) Availability of Raw Materials

Raw materials used in the Tanggui production is a nipah leaves to make the base (bakal) of the tanggui and rattan as a binder. Nipah leaves is a type of palm (Palma) that grows in mangrove forests or tidal seawater [18]. The findings show that nipah leaves can usually be sought by the craftsmen in Kembang Island or in the nearest estuary and also can be purchased through the nipah sellers for IDR 5,000.00 per bunch (Figure 6), while Rattan is usually bought through the collector (Figure 7). 


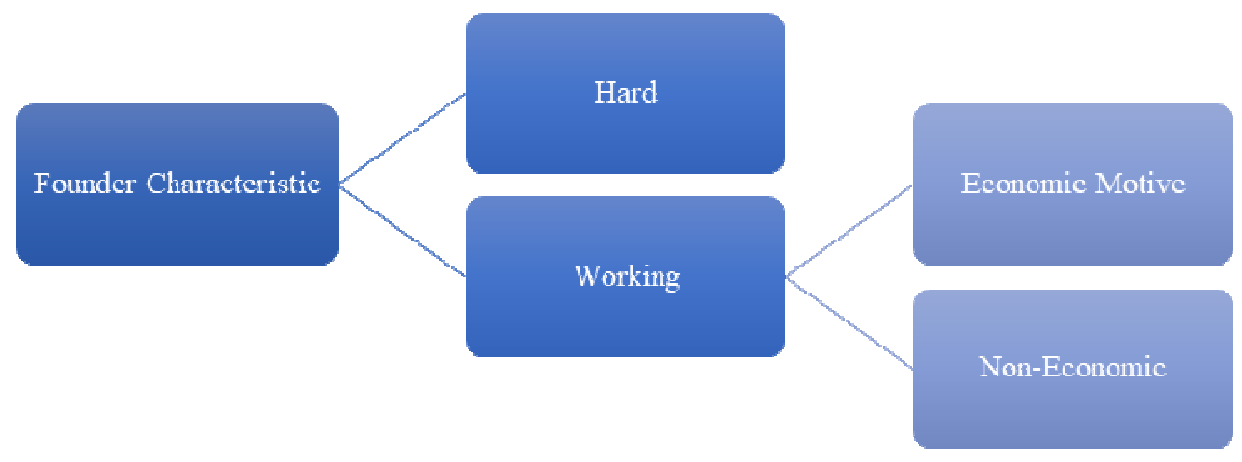

Figure 8 Survival factor of personal characteristic of the founder

5) Hard-working individual

Hard-working characteristic is important to maintain a business survival for entrepreneur like craftsmen. It is actually an internal factor found in someone showed by their diligent, active, hard worker, thrift action. Those factors are found in tanggui craftsmen daily routine, they intended to finish their work from dawn to night in order to complete customers' orders.

6) Motive to work

A certain motive is needed for someone to finish their work, so do the tanggui craftsmen. [20] found that a motive or motivation is a psychological force within an individual that sets him in motion for achievements of certain goals or satisfaction of certain needs. Motives or motivations found in tanggui craftsmen divided into economic motive and non-economic motive.

The motive often found in tanggui craftsmen to finish their work is an economic motive which is also include economy needs. [21] said that economic motive is a booster for someone to do economy activity in order to fulfill their economy needs. Beside the economc motive in order to fulfill their economy needs, the non-economic motive also found in some craftsmen. This non-economic motive is a perspective of tanggui craftsmen seeing their profession as a hobby not only a profession to get some money.

\subsubsection{Factor of "Bekawanan" strategy as industrial structure}

Building an industrial structure needs a strategy that can generate profit for a business [22]. States an industrial structure is something manifested in the competitive forces that sets industry profitability over the long run. The findings on Tanggui craftsmen states the strategy they are using is based on a kinship value developed in the local society, named "Bekawanan" strategy means doing and work together strategy. This strategy is manifested in their behavior to complete tanggui orders. The case often found is when one of tanggui craftsmen got many orders and couldn't finish it on scheduled time, the other tanggui craftsmen will help to complete the orders by division of tasks.

\subsubsection{Relevant work experience factors}

The craftsmen of Tanggui are found to have quite good work experience and related to their profession now. It mentioned that they can make crafts other than Tanggui. Those handicrafts are traditional mat, leaves roof, ketupat (compressed rice dish cooked in diamond-shaped molds made from coconut fronds) and flowers arrangement for the wedding or traditional event. The making of crafts signifies the skill of the craftsmen and becomes the asset of the craftsmen acquired from previous work experience. This is in line with the theory that the knowledge, skills, and creativity of a person is necessary for innovation in an attempt [10]. [9] explains innovation is a tool to capitalize on changes as opportunities for different businesses. The given innovation of making tanggui as a result of creativity, the business of Tanggui is likely will continue to survive.

The work experience made Tanggui craftsmen have other sources of income besides making Tanggui. The dimensions of their income sources are diverse, ranging from being a janitor at one of the local schools, to being a merchant. The craftsmen are also found not to be idle or always trying to find alternative income if there is a spare time besides making Tanggui. Judging from the side of the work experience and their willingness to fill free time to work, the craftsmen can be said to have the ability to survive and defend their business. This finding is in line with [19] stating that the business survival depends on the founder, mentioned that if the founder of a business is someone who has long been idle then significantly the business will be less successful and they will fail before finding other opportunities that exist in the market.

\section{CONCLUSION}

The findings of the research resulted in the conclusion of the existence of entrepreneurial survival values that developed and influenced the survival of craftsmen Tanggui in Alalak Selatan district. Those values are manifested to strategies which are: 1) determining the target market strategy to win the competition; 2) product development strategy by diverse the tanggui by its size, type and price; 3 ) pricing strategy determined by cost plus pricing or by the resulted price through the agreement 
between the craftsmen and the customer to increase customer demand; and 4) Ensuring the product quality by using good raw materials and resulting a neat tanggui. The development of values that manifested into strategy is influenced by some factors: 1) environmental conditions such as the availability of raw materials and the existence of tradition, cultural value and kinship value adopted by the local society; 2) Characteristics of the founders of enterprises that are hard workers and motivated in completing work that is divided into economic and noneconomic motives; 3 ) The use of the bekawanan strategy in the industrial structure and 4) relevant work experience before starting the business as Tanggui craftsmen. The implementation of kinship value and democracy is also found to influence the survival of Tanggui craftsmen in maintaining their business.

\section{REFERENCES}

[1] M. Riswan, "Problematika Pengembangan Ekonomi Kreatif Dalam Menunjang Sektor Pariwisata Di Kalimantan Selatan," J. Kebijak. Pembang., vol. 13, no. 2, pp. 129-139, 2018.

[2] S. Tanjaya, L. K. Wardani, and M. T. Rizqy, "Produk Interior Berbasis Budaya Kalimantan dengan Memanfaatkan Material Rotan," Intra, vol. 6, no. 2, pp. 266-275, 2018 .

[3] M. RATUMBUYSANG and F. N. GILLIAN, "PENGEMBANGAN EKONOMI KREATIF BERBASIS KEARIFAN LOKAL MELALUI" TANGGUI" TOPI KHAS BANJAR KALIMANTAN SELATAN," 2015.

[4] A. Campos Sánchez, "The Role of Personal Values in the Entrepreneurial Process," 2014.

[5] M. Mustari and M. T. Rahman, "Nilai karakter: Refleksi untuk pendidikan karakter." Laksbang Pressindo, 2011.

[6] A. K. Jha, T. W. Miner, and Z. Stanton-Geddes, Building urban resilience: principles, tools, and practice. The World Bank, 2013.

[7] M. Damis, "Strategi Kebertahanan Usaha Warung Kopi Tikala Manado Suatu Tinjauan Antropologi," HOLISTIK, J. Soc. Cult., 2018.

[8] F. J. da Rocha Neves, "Innovation and employment: an agent-based approach for studying the effects of technological change on the labor market," 2017.

[9] Y. Suryana and K. Bayu, Kewirausahaan: Pendekatan Karakteristik Wirausahawan Sukses Ed. 2. Kencana, 2012.

[10] R. J. Olughor and M. A. Oke, "The relationship between organizational survival and employee mental ability,” Int. J. Bus. Soc. Sci., vol. 5, no. 6, p. 1, 2014

[11] F. B. Prastyoko, D. Fanani, and M. K. Mawardi, "Strategi Pemasaran Kerajinan Gerabah Yang Berorientasi Ekspor Pada PT. Lombok Putri Cinderamata," J. Adm. Bisnis, vol. 30, no. 1, pp. 44-50, 2016.

[12] B. Permana, "STRATEGI KEBERTAHANAN PENGRAJIN INDUSTRI SANDAL DI DESA WEDORO KECAMATAN WARU KABUPATEN SIDOARJO," Swara Bhumi, vol. 3, no. 3, 2015.

[13] E. Sallis, Total quality management in education. Routledge, 2014.

[14] D. Nicolò, "Towards a theory on corporate reputation and survival of young firms," Procedia Econ. Financ., vol. 22, no. 2015, pp. 296-303, 2015.

[15] M. E. Pangestu, "Pengembangan ekonomi kreatif indonesia 2025," disampaikan dalam Konvensi Pengemb. Ekon. Kreat., vol. 20092015, 2008.

[16] C. S. Clauss-Ehlers, "Sociocultural factors, resilience, and coping: Support for a culturally sensitive measure of resilience," J. Appl. Dev. Psychol., vol. 29, no. 3, pp. 197-212, 2008.

[17] W. Rivaie, "Asimilasi nilai kekeluargaan lintas etnik," J. Ilm. Visi, vol. 6, no. 1, pp. 93-105, 2011.

[18] E. Subiandono, N. M. Heriyanto, and E. Karlina, "Potensi nipah (Nypa fruticans (Thunb.) Wurmb.) sebagai sumber pangan dari hutan mangrove," 2018.

[19] C. M. Van Praag, "Business survival and success of young small business owners," Small Bus. Econ., vol. 21, no. 1, pp. 1-17, 2003.

[20] S. Siddiqui and T. Singh, "Social media its impact with positive and negative aspects," Int. J. Comput. Appl. Technol. Res., vol. 5, no. 2, pp. 71-75, 2016.

[21] F. D. Patrikha, "Pengaruh Kelompok Referensi, Motif Ekonomi dan Pendidikan Kewirausahaan di Sekolah Terhadap Intensi Berwirausaha Siswa SMK di Kota Malang," J. Ekon. Pendidik. dan Kewirausahaan, vol. 3, no. 2, pp. 132-146, 2017.

[22] M. E. Porter, "Understanding industry structure," Harvard Bus. Sch., vol. 13, pp. 1-16, 2007. 